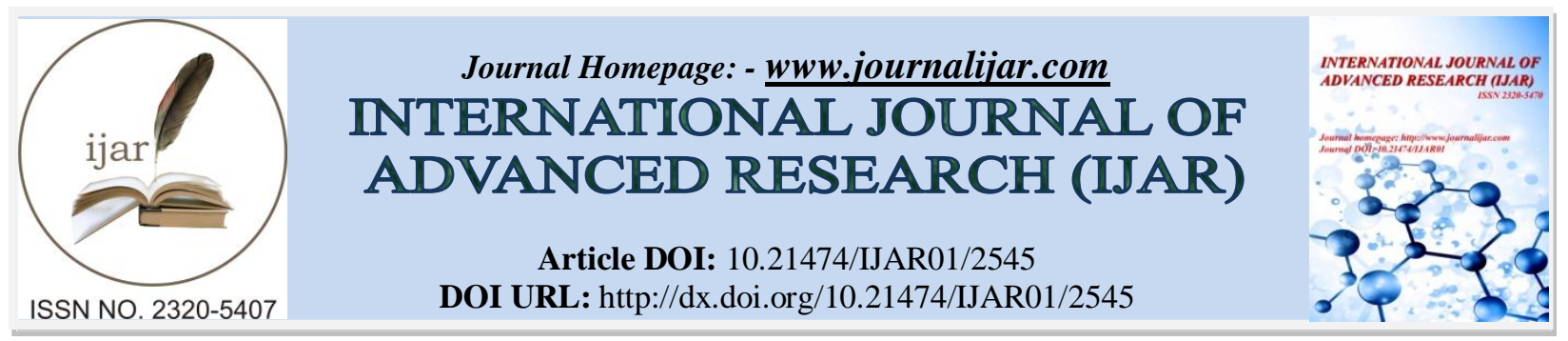

RESEARCH ARTICLE

\title{
EXISTENCE OF GLASS CEILING AND FACTORS AFFECTING WOMEN IN REACHING TOP POSITIONS.
}

Madhulata.

Research Scholar, BPSMV, Khanpur Kalan, Sonepat.

\section{Manuscript Info \\ Manuscript History \\ Received: 25 October 2016 \\ Final Accepted: 23 November 2016 \\ Published: December 2016}

\section{Abstract}

In today's technological period nations are on path of progress but progress of nations is also not supporting career advancement of women to top positions as studies revealed that gender based glass ceiling is found almost everywhere in the world it was found that almost all studies show existence of glass ceiling in abroad, two studies showed that in today's time glass ceiling is shattering and only one study revealed non-existence of glass ceiling abroad. In india also all studies show existence of glass ceiling, through review of literature critical factors were evaluated which leads to low representation of women in top positions and the sequence of factor effecting the most was organizational factor, personal factor, stereotyping factor, socio cultural factor, political factor and sexual harassment.

Copy Right, IJAR, 2016,. All rights reserved.

\section{Chapter 1:-}

\section{Introduction:-}

Chapter one gives a summary of glass ceiling origin how this term was coined up, why the need aroused to study status of women and minorities at their workplaces. What is the concept of glass ceiling? Findings of latest reports in magazines and periodicals are stated to have a glance at prevalence of glass ceiling in Indian. Includes glass ceiling index presented by economists to measure level of glass ceiling on basis of different parameters such as higher education, labor force participation, wage pay, child care cost, maternity rights, representation in senior jobs which are followed across countries to assess status of women at workplace among different nations. Also discussed on the key factors which promote glass ceiling by stopping women to rise to top level representations at workplaces such as social and cultural barrier, organizational barrier, governmental barrier, stereotype barrier and individual barrier. Framing of research questions, objectives, limitations and finally the significance of the study so as to make reader clear about how the study is structured and organized.

\section{Origin of the term:-}

The term was coined up in 1980s when several writers used this term, in the sense of barrier to advancement for women:-

In 1980 Katherine Lawrence originally introduced the concept of the glass ceiling in a Conference of the Women's Institute for Freedom press at Hewlett-Packard in U.S.

In 1984 Gay Bryant used the term in her book, "The Working Woman Report". And in the same year used by Adweek in his book "Women have reached a certain point -I call it the glass ceiling". 
In 1986 it was used in Wall Street Journal article on barriers to women in high corporate positions. This way the term become popularized and is being used continuously till date.

\section{Glass ceiling concept:-}

Glass ceiling is a metaphor in the business world which refers to an informal barrier through which it is hard-to-see and realize the upper limits in corporations and organizations, above which it is difficult or impossible for career advancement of women.

The U.S. Department of Labor's 1991 defines glass ceiling as those artificial barriers based on attitudinal or organizational bias that prevent qualified individuals from advancing upward in their organization into managementlevel positions.

According to business dictionary glass ceiling is an invisible but real barrier through which the level of advancement can be seen, but cannot be reached by a group of deserving and qualified employees.

\section{Prevalence of glass ceiling in Indian context:-}

Increased awareness and education has motivated women to come out of the walls of the houses. In modern India, women are representing high offices. They are actively participating in political, social and economic activities. Women like Chanda Kochhar, Kiran Mazumdar Shaw, Arundhati Bhattacharya, Kirthiga Reddy, Shereen Bhan, Ritu Kumar, Ekta Kapoor, Vinita Bali, Shahnaaz Hussain, are representing top executive positions of leading businesses in India.

While more women have entered the corporate boardrooms, still the overall scenario in India remains pretty grim.

In a study of catalyst analyses 2016, it was shown that women participation in labour force of India is falling. Out of 324 total executive directorship positions on the Bombay Stock Exchange hundred, only eight that account for 2.5 are held by women. 54\% of Companies on the Bombay Stock Exchange hundred are such which do not have any woman board director. Women holds 7.7 percent of board seat and just $2.7 \%$ of boards chairs which shows unbalanced placement of top positions between men and women.

India is placed at 114th position out of 142 countries in gender gap index 2015 , Index revealed $0.56 \%$ wage equality between female to male for similar work, $0.13 \%$ participation of women in Parliament and only 0.10 percent participation in ministerial position.

According to business standard report 2015, only $4 \%$ women are at senior positions in Indian corporate sector in comparison to $11 \%$ in Asia. According to 2016, Fortune 500 list just 21 companies CEO's are women which is only $4 \%$ that clearly shows evidences of Glass ceiling because where the contribution of women should be $50 \%$ is limited to $4 \%$ only.

Woman accounts for half of the worlds human resources which is equally important and should be given equal chances to prove themselves. According to finding of McKinsey global Institute (2015), $\$ 12$ trillion could be added to global GDP by advancing women equality. Countries with low involvement of women welfare are wasting their biggest resource.

This report also shows that percentage of incremental global GDP over business for India it is $16 \%$ which is higher than percentage increase of whole world (sample of 95 countries was taken) i.e. $11 \%$ so gender parity in India could add 0.7 trillion to its GDP this reveal importance and need of women empowerment in Indian economy.

Seven reports presented by women in global science and technology and the organization for women in Science for developing world conducted by experts in international gender, lowest rank was assigned to India for female participation in labor work force, knowledge economy participation, access to resources and health status in Science and Technology it was shown in study that in India even less than one third of Administrative and managerial position are held by women. 
Indra nooyi a famous business tycoon was elected the chairman of PepsiCo in 2007. She agreed in her one of the interviews that she has to work extra hard, more hours, more sacrifices and trade-offs, because being a woman and especially a person of color, were the two strikes against her.

Table 1:- Reports on participation of women in business and economy.

\begin{tabular}{|c|c|c|c|}
\hline Sr.No. & Report & Year & Findings \\
\hline 1 & $\begin{array}{l}\text { MC Kinsey Global Institute } \\
\text { Report }\end{array}$ & 2015 & $\begin{array}{l}\text { 12 trillion could be added to global } \\
\text { GDP by advancing women quality by } \\
2025 \\
\text { percentage of incremental global } \\
\text { GDP over business from today by } \\
\text { involvement of women for India it is } \\
16 \% \text { in comparison to } 11 \% \text { of world }\end{array}$ \\
\hline 2 & $\begin{array}{l}\text { MC Kinsey Global Institute } \\
\text { Report }\end{array}$ & 2016 & $\begin{array}{l}\text { Shows that women are still under } \\
\text { represented at every level in organizations. } \\
\text { Participation at: } \\
\text { Director position }=33 \% \\
\text { Vice presidential position }=29 \% \\
\text { Senior presidential position }=24 \% \\
\text { c-suite position }=19 \%\end{array}$ \\
\hline 3 & $\begin{array}{l}\text { Women in global science and } \\
\text { technology (WISAT) and The } \\
\text { organization for Women in } \\
\text { science for developing world } \\
\text { (OWSD) }\end{array}$ & 2014 & $\begin{array}{l}\text { lowest rank was assigned to India for } \\
\text { female participation labour work } \\
\text { force, knowledge economy } \\
\text { participation, access to resources and } \\
\text { health status in Science and } \\
\text { Technology } \\
\text { Even less than one third of } \\
\text { Administrative and managerial } \\
\text { position are held by women in India }\end{array}$ \\
\hline 4 & Gender Gap Index Report & 2015 & $\begin{array}{l}\text { India placed } 114^{\text {th }} \text { out of } 142 \text { countries } \\
0.56 \% \text { of wage equality between } \\
\text { female and male } \\
0.13 \% \text { participation of women in } \\
\text { parliament } \\
0.10 \% \text { participation of women in } \\
\text { ministerial positions }\end{array}$ \\
\hline 5 & Business Standard Report & 2015 & $\begin{array}{l}\text { Only } 4 \% \text { women are at senior positions in } \\
\text { India comparison to } 11 \% \text { in Asia }\end{array}$ \\
\hline 6 & Study of Catalyst analysis & 2016 & $\begin{array}{l}\text { Out of } 324 \text { total executive directorship } \\
\text { positions on the Bombay stock } \\
\text { exchange 100,only } 8 \text { that accounts for } \\
2.5 \% \text { are held by women } \\
54 \% \text { of companies on the Bombay } \\
\text { stock exchange } 100 \text { have no women } \\
\text { board directors }\end{array}$ \\
\hline 7 & Fortune 500 List & 2016 & $\begin{array}{l}\text { Just } 21 \text { companies CEO's are women } \\
\text { among top } 500 \text { companies that accounts } \\
\text { for only } 4 \%\end{array}$ \\
\hline 8 & $\begin{array}{l}\text { Grant Thornton International } \\
\text { Business Report }\end{array}$ & 2015 & $\begin{array}{l}\text { revealed that there is reduction in women } \\
\text { participation at senior position in North } \\
\text { America and European companies but in } \\
\text { India this percentage has raised to } 14 \%\end{array}$ \\
\hline
\end{tabular}


Factors affecting glass ceiling:-

Social and cultural Barrier:-

Culture is all socially generation to generation passed on behavior, arts, languages, architectures, symbols, signs, ideas, beliefs, traditions, norms, rituals, etc. which is learnt and influenced by the attitudes, customs and practices of people sharing's in a particular social group of the same nationality, religion, ethnicity etc. Some cultures do not allow women to go out of homes, they are restricted to household works and some culture does not support women taking challenging jobs. This way women participation in economy is curtailed.

Organizational Barriers:-

This is a barrier caused due to biased recruitment practices, unsupportive corporate climate and culture for women, lack of opportunities of training and education for women to advance into management positions, biased performance appraisal methods etc.

Governmental Barriers:-

No strong provisions made by government regarding reporting systems that address the glass ceiling in organizations, delay in justice by courts, poor maintenance and follow-up of plans and policies which are enforced regarding glass ceiling, lack of prevention programs and consistent monitoring required to stop glass ceiling.

\section{Stereotypes Barrier:-}

This barrier is caused due to differences created between human groups and their potential limit interaction. Such as on basis of race, gender, religion or language. Due to this problem women limit their potentials due to other society member's conscious or unconscious prejudices.

Stereotype refers to the attitude that people holds about an individual or group. According to William and best study from 1992 males are characterized as powerful, domineering, adventurous and independent on the other hand female are characterized as submissive, sentimental and superstitious across 30 different countries.

\section{Individual Barrier:-}

Sometimes Women herself becomes barrier for her career advancement such as inability to give proper time, lack of initiatives for challenging jobs, fear of taking leadership responsibilities, more concerns to family and children etc. are the individual factors that impedes the career advancement of women.

Why study glass ceiling:-

1. To identify the existence of glass ceiling.

2. To identify the thickness of glass ceiling.

3. To identify the barriers that prevents women from being promoted to higher positions.

4. To offer recommendations that help to enhance women's career advancement.

The research Questions derived from these areas are as follows:

1. Does the glass ceiling exist?

2. What is the thickness of glass ceiling?

3. What are the barriers that prevent women from being promoted to higher positions?

\section{Statement of the Problem:-}

The Problem selected for investigation in the present study has been titled as "EXISTENCE OF GLASS CEILING AND FACTORS AFFECTING WOMEN IN REACHING TOP POSITIONS”

\section{Objectives of the study:-}

The study had following objectives:

1. To study status of glass ceiling in India and abroad

2. To identify the factors affecting women in reaching top positions

\section{Limitations of the study:-}

Since the study is secondary based, data provided by others was considered as reliable and no specific technique was used to check reliability of other sources data. 


\section{Significance of the study;-}

This study focus is to reveal the existence of glass ceiling in India and abroad. It focuses on finding factors affecting glass ceiling and its thickness on basis of gender through review of literature of researches done in India and abroad to reveal the invisible barriers hindering the career advancement of women. The government and non government organizations which are helping women may use the knowledge in removing hurdles which are responsible for career advancement of women to reach top positions.

\section{Chapter 2:- \\ Literature review:- \\ Introduction:-}

In this chapter, an attempt has been made to present a review of studies on glass ceiling practices with working woman. Published work on glass ceiling practices with working women has provided guidance for the present study. In the following paragraphs a brief survey of some of those important researches is given to provides an insight into gender inequalities; It aims to seek the reasons for the existence of the glass ceiling, low representation of women on top positions, longitudinal analysis of glass ceiling, thickness over times and barriers which impedes the career advancement of women in organizations.

\section{Gender based wage gap:-}

Levitt, P. et al. (2009) found through a set of 2000 census data by fitting three- level hierarchical linear models that greater the women representation in management narrow is the gender wage gap so concluded that promotion of women in management may benefit all woman. Supporting the same point, Joshi, A. et al. (2014) has found sex differences in performance evaluations and rewards between men and women that due to sex differences reward was 14 times greater than performance and also revealed that in top level representations of female executive there was no gap in the reward and performance. On the other hand Smith Ryan, A. (2006) found that glass ceiling does not increase or decrease with higher authority rather relative inequality remains at both higher and lower authority levels. On the contrary Cotter, R. et al. (2008) revealed that middle managers among women face glass ceiling the most in working environment through analysis of glass ceiling with regard to corporate climate, culture and corporate practices.

Many of the social sciences studies report only on gender Cotter et al. $(1999,2001)$ focused on both race/ethnicity and gender by using random effect model to study income dynamics from panel study in Columbia to examine race and gender inequalities at the $25^{\text {th }}, 50^{\text {th }}$ and $75^{\text {th }}$ percentile of white male earnings found evidences for glass ceiling for women but denied the existence of it among different races and so revealed glass ceilings as a gender phenomenon. Wage gaps also supported by Robert study on how thick is glass ceiling in Australia across all occupations found a man is 4.6 times more likely to get promotions and Earns \$24 more than women per annum and study of Lee supported that this income gap is widening.

Fernandez, M. (2005) on basis of quantitative interviews from Asian Indian Americans in the Bay area found that Asian Indian females are less promoted in becoming managers and earn less in comparison to U.S. born

\section{Gender based inequality in top level representations:-}

Len J. Trevino et al (2015) examined the evidence to determine the glass ceiling problem in senior positions in business colleges of U.S.A, found that after controlling other factors, women are less awarded with professorship. This gender disparity is a sign of masculinized organizational practices that frame policies and promotion in business schools. In addition worked on conceptual frameworks, namely expectations state theory, homophile and hegemonic masculinities, shifting standards theory and social role theory to provide theoretical insights into how unintentionally gender biasness can enter into the promotion process of business schools. On the other hand findings of Ryan A Smith (2013) imply on both women as well as on minorities that they face lower odds for achieving higher level at workplace in comparison to man and it was also found that black women are victims of direct discrimination. Sharma, A. (2011) also investigated glass ceiling in education Sector through responses of 240 faculty members from 42 colleges and found significant differences on basis of gender. One of the major reasons found was that women is not assigned any administrative tasks, also observed that women employees lack tremendously in getting mentors, supporting the same point study of Nieva and Gutek (1981) revealed that in some cases, women leader may take help from their mentors but are not so successful as male leaders due to gender issues. 
Kewaku Ohemeng, Frank L. et al. (2013) found that in Ghana out of 36 positions for chief directors of a ministry only 6 were filled by women, creating glass ceiling in the service. The study specifically targeted the role of government in framing and implementation of policies for women career advancement in service sector. In Indian cooperative sector context Nandy, S. et al. (2014) studied three barriers of Glass ceiling as psychological barriers, social- related barrier and organizational barriers and found the evidences of glass ceiling showing evidences of lower representations of women in top level positions.

Huffman, Matt L. et al. (2014) in his study analyzed 1000 Ambassador appointment from 50 top countries in terms of GDP in 2014 result shown that gender gap is also linked to power and status, female ambassadors have less chances to occupy high status ambassadorship in comparison to man. Folke, O. (2014) also supported by study in Sweden in politics that glass ceiling hinders elected women's to rise to political power.

\section{Longitudinal studies on glass ceiling:-}

Hermsen, C. et al. (2007) Presented four criteria's for distinguishing the glass ceiling which includes one as longitudinal data which was also followed by David J. Maume Jr. which satisfied Cotter. Et al. criteria regarding existence of Glass ceiling along with these longitudinal study was investigated by Stroh, Linda K. et al. (2008) with differential turnover rates between male and female managers of 20 Fortune 500 companies and his findings also satisfied the existence of Glass ceiling. Whereas Arfken, Deborah E. et al. (2004) examined by comparing data to original study conducted in 1995 in state of Tennessee found only a modest improvement in presence of women on corporate boards. Only modest improvements was supported by findings of Martin, M. (2010) who investigated through case study and found increase percentage of women participation in senior executive service in Federal agencies of USA from $23 \%$ to $30 \%$ from 1999 to 2009 . On the other side few supported only a weak evidences of glass ceiling in a study Nath, D. (2000) found that India's workforce is changing; women managers in India are rising to executive suite in Indian organizations due to interplay of organizational, families support and individual drive for success on basis of comparisons of past to current data. Baxter, J. et al. (2000) worked on comparative study of the United States, Australia and Sweden found no systematic glass ceiling effects in U.S and only weak evidences from Australia and Sweden were found.

Researches such as Deszo \& Ross (2008) and Adler (2001) showed that female participation in the board of the company has a positive effect on firm performance, on the other hand study of Andreea Petre,R. (2010) argues that by analyzing the influence of women in the executive suite across different samples of firms (LTD, and PLC) which were divided into two time periods (prior Norwegian gender quota 2000-2004, and post Norwegian quota 2005-2009) and showed that having a woman CEO has a neutral or negative effect on performance of the firm.

According to Folke, O. (2014) the cross-sectional method fails to some extent because all individuals do not enter the organization at the lowest level. There may be chances of majority men entering at higher levels which leads to over-representation of majority men at higher levels.

\section{Barriers in career advancement of women:- Organsational barriers:-}

Hoobler, Jenny M. (2009) presented model based on social role theory and examined 112 sample of supervisor subordinate from U.S. Fortune 500 firms found that, challenging work, training and career encouragement are less provided for women which lacks in organizational developments. Whereas Mattis, Mary C. (2007) interviewed women business owners who left corporate and found that reason for their employee turnover was glass ceiling such as lack of flexibility, lack of access to line positions, lack of role models and failure of organization to reward contribution of women. The study of Buzzanell, Patrice M. (2000) discuss on current organizational practices which has failed to alter power imbalance in content to alternative settings (which include organizational forms) process (community) and Organization member (women). Through cross-sectional survey with 475 respondents of different colleges Myres, C. (2016) found that job opportunities, internal structure and organizational culture are the most important factors for glass ceiling in career advancement of women community.

Afza, S. (2008) in his study took five factor groups by factor analysis to study Glass ceiling as management perception, work- environment, work- life conflict, sexual harassment and organizational policy and found through opinion of respondents most important factors were management perception and work environment and second most important were Organizational conflict and work life conflict. This study also disagreed for sexual harassment as a contributor for creating glass ceiling. Focus of findings of Al-Manassa, E. (2013) was also on organsational barrier 
where he explored the impact of Glass ceiling barriers in Jordan by including organizational, family and social barriers.

\section{Personal barrier:-}

Van Vianen, A. et al. (2002) investigated 327 sample to study gender differences in culture performances of organizations found that gender differences existed only in managerial group and that to because woman shows less Masculine cultural preferences, less ambition than men and even ambitious woman faced barriers to career advancement due to work- home conflict. Carrying the FOS study by Cody Bullock, Christina Lewis and Chrlene Bainum (2004) displayed significant response of women which means in today's time also women fear of success is not allowing her to achieve carrier promotions. On the other hand Morrison, Ann. M. (1999) survey of 200 managers in sixteen model organizations shows two barriers which managers see in an organization were discomfort and the lack of accountability. Jarmon, Lori J. (2014), in his qualitative phenomenological study through In-depth interviews from seven women in senior level administrative positions in the Midwest found that there is need for women to be more motivated about their career aspirations and also identified requirement of many institutional changes so as to provide equal opportunities for women to reach to senior level administrative positions in higher education.

Chamaru, Bombuwela A. (2013) studied significance of four factors in Sri Lanka through questionnaire with sample size of 150 female executive. Factors includes individual factors, organizational factors, cultural factors and family factors and found that family practice has major impact on glass ceiling. Contrary to Double Burden syndrome Stroh, Linda K. et al. (2008) found that female managers intention to leave was not because of family structure but due to perception of lack of career opportunities, job dissatisfaction and disloyalty to the company. As given by Van Vianen \& Fischer (2002) women tacitly agrees to these discrimination and glass ceiling and in turn become less ambitious.

\section{Socio-cultural barrier:-}

Reynolds, A. (2011) surveyed women executives around the world to study factors hindering women access to political representation tested by multivariate regression models on a cocktail of political institutional, cultural and socioeconomic variables found that socioeconomic development has effect on women in Parliament but not in cabinet.

Omotayo,O. et al. (2008) has empirically surveyed effects of Glass ceiling in Nigerian Police Force (NP) with 198 respondents it was found that the cultural role expected from female was most significant reason for glass ceiling.

\section{Stereotyping barrier}

Lawanson, Olukemi I. (2007) in his study introduced 6 barriers to study glass ceiling in Nigeria 1) Religion/cultural/social 2) institutional/organizational/structural 3) legislation/ political barrier 4) Educational barrier 5) gender based barrier 6) political/leadership barrier and surveyed 100 male and female engaged in labour found that Nigerian women are considered inferior to men, sex role and stereotyping impede the progress of women and also found women are believed to be less intelligent than men.

Schwarts (1989) also articulated stereotyping as the major reason for existence of glass ceiling. Supported by study of Thi Thu Thao Tran (2014) who conducted data analysis through quantitative and qualitative methods revealed that glass ceiling is existing in Vietnamese banking sector and reasons for glass ceiling includes social stereotype, family- work conflict, women themselves and corporate practices.

Budhawar et al. (2005) also found stereotyping as the main barrier because of which women are offered less challenging roles and are not involved in important organizational issue

Table 2:- On basis of review of literature of abroad

\begin{tabular}{|l|l|l|l|l|}
\hline Sr. No & Author name & Title & Country & Findings \\
\hline 1 & $\begin{array}{l}\text { Robert Dapice } \\
(2015)\end{array}$ & $\begin{array}{l}\text { Wage gaps and its impact on } \\
\text { economies }\end{array}$ & Australia & $\begin{array}{l}\text { Found across all occupations in } \\
\text { Australia a man is 4.6 times more } \\
\text { likely to reach a high paying role } \\
\text { than a woman }\end{array}$ \\
\hline
\end{tabular}




\begin{tabular}{|c|c|c|c|c|}
\hline 2 & $\begin{array}{l}\text { Len J.Trevino.et al. } \\
(2015)\end{array}$ & $\begin{array}{l}\text { Meritocracies or masculinities? } \\
\text { The differential allocation of } \\
\text { named professorship by gender } \\
\text { in the academy }\end{array}$ & U.S.A & $\begin{array}{l}\text { On bass of sample of } 511 \\
\text { management professors, found } \\
\text { women get less chances to endow } \\
\text { chair specially when choice is } \\
\text { among internal candidates }\end{array}$ \\
\hline 3 & $\begin{array}{l}\text { Aparna Joshi .et al. } \\
\text { (2014) }\end{array}$ & $\begin{array}{l}\text { When can women close the } \\
\text { gap? A meta-analytical test of } \\
\text { sex differences in performance } \\
\text { and rewards }\end{array}$ & U.S.A & $\begin{array}{l}\text { Founds that the sex differences in } \\
\text { reward }(\mathrm{d}=.56) \text { were } 14 \text { times } \\
\text { larger than sex differences in } \\
\text { performance evaluation }(\mathrm{d}=.04)\end{array}$ \\
\hline 4 & $\begin{array}{l}\text { Matt 1.Huffman.et al. } \\
\text { (2014) }\end{array}$ & $\begin{array}{l}\text { Equality for whom? } \\
\text { Organizational policies and the } \\
\text { gender gap across the German } \\
\text { earning distribution }\end{array}$ & Germany & $\begin{array}{l}\text { On basis of different factors } \\
\text { suggest that gender policies have } \\
\text { more subtle effect on wage } \\
\text { inequality }\end{array}$ \\
\hline 5 & $\begin{array}{l}\text { Thi Thao Tran } \\
\text { (2014) }\end{array}$ & $\begin{array}{l}\text { Identifying the existence of the } \\
\text { glass ceiling and examining } \\
\text { the impact on the participation } \\
\text { of female executives in the } \\
\text { Vietnamese's banking sector }\end{array}$ & Vietnamese & $\begin{array}{l}\text { Data analysis through quantative } \\
\text { and qualitative methods revealed } \\
\text { that glass ceiling exist in } \\
\text { Vietnamese banking sectors } \\
\text { obstacles includes individual, } \\
\text { corporate and social }\end{array}$ \\
\hline 6 & $\begin{array}{l}\text { Olle Folke .et al. } \\
\text { (2014) }\end{array}$ & $\begin{array}{l}\text { The glass ceiling in politics } \\
\text { formalization and empirical } \\
\text { data }\end{array}$ & Sweden & $\begin{array}{l}\text { The result supports that glass } \\
\text { ceiling is hindering women's rise } \\
\text { to political power }\end{array}$ \\
\hline 7 & $\begin{array}{l}\text { Frank 1. Kwaku } \\
\text { Ohemeng } \\
(2013)\end{array}$ & $\begin{array}{l}\text { Breaking through the glass } \\
\text { ceiling :strategies to enhance } \\
\text { the advancement of women in } \\
\text { Ghana's public services }\end{array}$ & Canada & $\begin{array}{l}\text { Considerable progress was fond } \\
\text { in Ghana regarding participation } \\
\text { of women in civil services etc. }\end{array}$ \\
\hline 8 & $\begin{array}{l}\text { Ryan A.Smith } \\
\text { (2013) }\end{array}$ & $\begin{array}{l}\text { Money, benefits and power: a } \\
\text { test of the glass ceiling and } \\
\text { glass escalator hypothesis }\end{array}$ & U.S.A & $\begin{array}{l}\text { Finds white male advantage over } \\
\text { women and minorities }\end{array}$ \\
\hline 9 & $\begin{array}{l}\text { Bombuwela P.M } \\
\text { (2013) }\end{array}$ & $\begin{array}{l}\text { Effects of Glass Ceiling on } \\
\text { Women Career Development } \\
\text { in Private Sector Organizations } \\
\text { - Case of Sri Lanka. }\end{array}$ & Sri-Lanka & $\begin{array}{l}\text { Significance of four factors was } \\
\text { found influencing glass celing } \\
\text { with sample size of } 150 \text { female } \\
\text { executives }\end{array}$ \\
\hline 10 & $\begin{array}{l}\text { Smith P. Critienden, } \\
(2012)\end{array}$ & $\begin{array}{l}\text { Measuring women's beliefs } \\
\text { about glass ceilings: } \\
\text { development of the career } \\
\text { pathways survey, gender } \\
\text { management }\end{array}$ & Sweden & $\begin{array}{l}\text { The survey revealed the } \\
\text { quantitative comparisons of } \\
\text { women's beliefs about glass } \\
\text { ceiling }\end{array}$ \\
\hline 11 & $\begin{array}{lll}\begin{array}{l}\text { Stephanie } \\
\text { (2011) }\end{array} & \text { T. Jones } \\
\end{array}$ & $\begin{array}{l}\text { Glass ceilings and catfights: } \\
\text { Career barriers for professional } \\
\text { women in academia. }\end{array}$ & Australia & $\begin{array}{l}\text { Identified that a majority of } \\
\text { females felt their peers were } \\
\text { supportive for their career } \\
\text { advancement }\end{array}$ \\
\hline 12 & $\begin{array}{l}\text { Andrew Reynolds } \\
(2011)\end{array}$ & $\begin{array}{l}\text { Women in legislature and } \\
\text { executives of the world: } \\
\text { knocking at the highest glass } \\
\text { ceiling }\end{array}$ & $\begin{array}{l}\text { Cross } \\
\text { countries }\end{array}$ & $\begin{array}{l}\text { By testing women in political } \\
\text { representations by multivariate } \\
\text { regression model founds } \\
\text { democracy is not good indicator } \\
\text { of women presence into the } \\
\text { legislature or cabinet }\end{array}$ \\
\hline 13 & Cheryl Myers (2010) & $\begin{array}{l}\text { "Perceptions of the Glass } \\
\text { Ceiling Effect in Community } \\
\text { Colleges" }\end{array}$ & U.S.A & $\begin{array}{l}\text { Job opportunities, internal } \\
\text { structure, organizational culture } \\
\text { were found as the most important } \\
\text { factors leading to glass ceiling }\end{array}$ \\
\hline 14 & $\begin{array}{l}\text { Randala } \\
\text { (2010) }\end{array}$ & $\begin{array}{l}\text { Glass Ceiling, women in } \\
\text { management }\end{array}$ & Jamica & $\begin{array}{l}\text { Found that prejudices and } \\
\text { Biasness was the worst enemy for } \\
\text { women career. }\end{array}$ \\
\hline
\end{tabular}




\begin{tabular}{|c|c|c|c|c|}
\hline 15 & $\begin{array}{l}\text { Megan } \\
\text { Martin } \\
(2010)\end{array}$ & $\begin{array}{l}\text { The Glass Ceiling: An } \\
\text { Analysis of Women Working } \\
\text { for Federal Agencies. }\end{array}$ & U.S.A & $\begin{array}{l}\text { Investigated through case study } \\
\text { and found increase of } 10 \% \\
\text { women participation in senior } \\
\text { executive services in federal } \\
\text { agencies of U.S.A }\end{array}$ \\
\hline 16 & $\begin{array}{ll}\text { Tianna, } & \text { Nichole } \\
\text { Joseph (2010) }\end{array}$ & $\begin{array}{l}\text { Discrimination glass ceiling } \\
\text { and Chinese } \\
\text { Americans. }\end{array}$ & U.S.A & $\begin{array}{l}\text { This paper focused on glass } \\
\text { ceiling practices prevailing in } \\
\text { America especially in respect to } \\
\text { Asians Americans. }\end{array}$ \\
\hline 17 & $\begin{array}{l}\text { Zahid Ali Channar } \\
\text { (2010) }\end{array}$ & $\begin{array}{l}\text { Gender discrimination in } \\
\text { workforce through sticky floor } \\
\& \text { glass ceiling effects. }\end{array}$ & Pakistan & $\begin{array}{l}\text { Examined public and private } \\
\text { health and educational } \\
\text { departments through wage gaps } \\
\text { and promotions and shows } \\
\text { discrimination on basis of gender }\end{array}$ \\
\hline 18 & $\begin{array}{l}\text { Jenny m. Hoobler.et } \\
\text { al. } \\
\text { (2009) }\end{array}$ & $\begin{array}{l}\text { Women's managerial } \\
\text { aspirations an organizational } \\
\text { development perspective }\end{array}$ & Chicago & $\begin{array}{l}\text { Model based on social role theory } \\
\text { examined sample of } 112 \\
\text { supervisors of fortune } 500 \text { firms } \\
\text { explained reason of glass ceiling } \\
\text { as women have lower managerial } \\
\text { aspirations }\end{array}$ \\
\hline 19 & $\begin{array}{l}\text { Lind k. stroh .et al. } \\
(2008)\end{array}$ & $\begin{array}{l}\text { Family structure, glass ceiling } \\
\text { and traditional explanations for } \\
\text { the differential rate of turnover } \\
\text { of female and male managers }\end{array}$ & $\begin{array}{l}\text { Cross } \\
\text { countries }\end{array}$ & $\begin{array}{l}\text { Longitudinal study investigated } \\
\text { turnover rates between female } \\
\text { and male fortune } 500 \text { companies } \\
\text { found more turnover by female } \\
\text { headed companies due to } \\
\text { different reasons }\end{array}$ \\
\hline 20 & $\begin{array}{l}\text { David A.Cotter et al. } \\
\text { (2008) }\end{array}$ & The glass ceiling effect & Columbia & $\begin{array}{l}\text { Using random effects model data } \\
\text { from panel study of income } \\
\text { dynamics found evidence of glass } \\
\text { ceiling for women }\end{array}$ \\
\hline 21 & $\begin{array}{l}\text { Gary N.Powell.et al. } \\
(2008)\end{array}$ & $\begin{array}{l}\text { Investigating the glass ceiling } \\
\text { phenomenon: an empirical } \\
\text { study of actual promotion to } \\
\text { top management }\end{array}$ & U.S & $\begin{array}{l}\text { Examined promotions for U.S } \\
\text { federal government found job } \\
\text { irrelevant variables leading to } \\
\text { women advancement to top than } \\
\text { to job relevant variables }\end{array}$ \\
\hline 22 & $\begin{array}{l}\text { Syeda Rownak Afza } \\
(2008)\end{array}$ & $\begin{array}{l}\text { Factors Determining the } \\
\text { Presence of Glass Ceiling and } \\
\text { Influencing Women Career } \\
\text { Advancement in Bangladesh. }\end{array}$ & Bangladesh & $\begin{array}{l}\text { Took five factors to study glass } \\
\text { ceiling and found most important } \\
\text { were management perception and } \\
\text { work environment }\end{array}$ \\
\hline 23 & $\begin{array}{l}\text { Olukemi Lawanson } \\
(2007)\end{array}$ & $\begin{array}{l}\text { The Effect of Glass Ceiling on } \\
\text { Working Women: A Case } \\
\text { Study of Nigeria }\end{array}$ & Nigeria & $\begin{array}{l}\text { Found that Nigerian women are } \\
\text { considered inferior to men. Sex } \\
\text { role and stereotyping impede the } \\
\text { progress of women }\end{array}$ \\
\hline 24 & $\begin{array}{l}\text { Brenda J. Wringley } \\
\text { (2007) }\end{array}$ & $\begin{array}{l}\text { Glass ceiling in public relation } \\
\text { communication management }\end{array}$ & Norway & $\begin{array}{l}\text { Studies the existence of glass } \\
\text { ceiling and identified five factors } \\
\text { affecting it }\end{array}$ \\
\hline 25 & $\begin{array}{l}\text { Marry C.Mattis.et al. } \\
(2007)\end{array}$ & $\begin{array}{l}\text { Women entrepreneurs: out } \\
\text { from under the glass ceiling }\end{array}$ & U.S.A & $\begin{array}{l}\text { Women entrepreneurs who left } \\
\text { company career said glass ceiling } \\
\text { was the major reason for leaving } \\
\text { earlier job }\end{array}$ \\
\hline 26 & $\begin{array}{l}\text { Ann.towns.et,al } \\
(2007)\end{array}$ & $\begin{array}{l}\text { Gender, international status } \\
\text {,ambassador appointments }\end{array}$ & $\begin{array}{l}\text { Cross } \\
\text { countries }\end{array}$ & $\begin{array}{l}\text { Analyzed through } 7000 \\
\text { ambassador appointments by } 50 \\
\text { highest GDP ranked countries } \\
\text { show females are less likely to } \\
\text { occupy high ambassadorship than } \\
\text { man }\end{array}$ \\
\hline
\end{tabular}




\begin{tabular}{|c|c|c|c|c|}
\hline 27 & Dudu Msomi (2006) & $\begin{array}{l}\text { Factors affecting women } \\
\text { representation on boards of } \\
\text { directors in South African } \\
\text { companies }\end{array}$ & South Africa & $\begin{array}{l}\text { Focused on the factors that affect } \\
\text { representation of women on } \\
\text { board in south African companies } \\
\text { and discussed the strategies that } \\
\text { can be applied to increase } \\
\text { representation. }\end{array}$ \\
\hline 28 & $\begin{array}{l}\text { Sebawit G.Bishu } \\
(2006)\end{array}$ & $\begin{array}{l}\text { A systematic review of the } \\
\text { gender pay gap and factors that } \\
\text { predict glass ceiling }\end{array}$ & U.S.A & $\begin{array}{l}98 \text { Peer-reviewed articles were } \\
\text { investigated in public sector less } \\
\text { gender pay gaps were found }\end{array}$ \\
\hline 29 & $\begin{array}{l}\text { Philip n. cohen } \\
\quad(2006)\end{array}$ & $\begin{array}{l}\text { Working for the women? } \\
\text { Female managers and the } \\
\text { gender wage gap }\end{array}$ & California & $\begin{array}{l}\text { Result from three level } \\
\text { hierarchical linear model from } \\
2000 \text { census that greater } \\
\text { participation of women is } \\
\text { minimizing the gender gap }\end{array}$ \\
\hline 30 & $\begin{array}{l}\text { Christine } \quad \text { Barnet. } \\
\text { Verzat } \\
(2006)\end{array}$ & $\begin{array}{l}\text { Gender wage gap and the glass } \\
\text { ceiling effect a firm level } \\
\text { investigation. }\end{array}$ & Korea & $\begin{array}{l}\text { Found that there are differences } \\
\text { in labor market characteristics } \\
\text { between men and women. and } \\
\text { women get lower chances to } \\
\text { reach higher hierarchical } \\
\text { positions within the firm. }\end{array}$ \\
\hline 31 & $\begin{array}{l}\text { Marilyn Fernandez } \\
\text { (2005) }\end{array}$ & $\begin{array}{l}\text { Asian Indian American in the } \\
\text { Bay area and the glass ceiling }\end{array}$ & Bay area & $\begin{array}{l}\text { On the basis of interviews in Bay } \\
\text { area founds that Asian Indian } \\
\text { women faces glass ceiling they } \\
\text { are less promoted to higher } \\
\text { positions in comparison to U.S } \\
\text { white women }\end{array}$ \\
\hline 32 & $\begin{array}{l}\text { Prudence La } \text { beach } \\
\text { Pollard (2005): }\end{array}$ & $\begin{array}{l}\text { A critical analysis of gender } \\
\text { and compensation. }\end{array}$ & South Africa & $\begin{array}{l}\text { Explored work place challenges } \\
\text { that women face and } \\
\text { recommended strategies through } \\
\text { research and policy at } \\
\text { organizational and governmental } \\
\text { levels }\end{array}$ \\
\hline 33 & $\begin{array}{l}\text { Vimolwan } \\
\text { Yukongdi .et al. } \\
(2005)\end{array}$ & $\begin{array}{l}\text { Women in Asian management: } \\
\text { cracking the glass ceiling? }\end{array}$ & Asia & $\begin{array}{l}\text { According to study Asia has rapid } \\
\text { growth in economies but their } \\
\text { impact on women career } \\
\text { advancement was found to be low }\end{array}$ \\
\hline 34 & $\begin{array}{l}\text { James r.elliott et.al } \\
(2005)\end{array}$ & $\begin{array}{l}\text { Race, gender and workplace } \\
\text { power }\end{array}$ & Orleans & $\begin{array}{l}\text { White men achieve higher levels } \\
\text { of power on the other hand } \\
\text { women and minorities face lower } \\
\text { odds }\end{array}$ \\
\hline 35 & $\begin{array}{l}\text { Chen, Li.Yu Isabel } \\
\text { (2005) }\end{array}$ & $\begin{array}{l}\text { Glass ceiling and strategies for } \\
\text { women's } \\
\text { career advancement }\end{array}$ & China & $\begin{array}{l}\text { Found five positive strategies to } \\
\text { break glass ceiling such as } \\
\text { advanced education and training, } \\
\text { internal networking career } \\
\text { tracking, formal monitoring and } \\
\text { exceeding } \\
\text { Performance expectations. }\end{array}$ \\
\hline
\end{tabular}

Table 3:- On basis of review of literature of India.

\begin{tabular}{|l|l|l|l|}
\hline Sr.No & Author name & Title & Findings \\
\hline 1 & $\begin{array}{l}\text { Radha Yadav et al. } \\
(2014)\end{array}$ & $\begin{array}{l}\text { Through secondary research on listed } \\
\text { companies found that only few women on } \\
\text { top positions due to barriers which stops } \\
\text { their career advancement }\end{array}$ \\
\hline 2 & $\begin{array}{l}\text { Sarmistha Nandy } \\
\text { (2014) }\end{array}$ & $\begin{array}{l}\text { Corporate Glass Ceiling: An Impact } \\
\text { on Corporate Glass Ceiling. }\end{array}$ & $\begin{array}{l}\text { Study shows existence of glass ceiling } \\
\text { due to three barriers psychological, } \\
\text { societal related and organizational barrier } \\
\text { in Indian corporate sector }\end{array}$ \\
\hline
\end{tabular}




\begin{tabular}{|c|c|c|c|}
\hline 3 & $\begin{array}{l}\text { Shikha Srilatha } \\
(2014)\end{array}$ & $\begin{array}{l}\text { Gender disparity in boardrooms: a } \\
\text { global and local perspective }\end{array}$ & $\begin{array}{l}\text { Found that top companies in India are } \\
\text { demanding gender diversity and through } \\
\text { examining status of glass ceiling in } \\
\text { abroad and India found low } \\
\text { representation of women on top positions } \\
\text { is still a serious issue }\end{array}$ \\
\hline 4 & $\begin{array}{l}\text { Anita Sharma } \\
\text { (2011) }\end{array}$ & $\begin{array}{l}\text { An Exploratory Study of Glass } \\
\text { Ceiling in Indian Education Sector }\end{array}$ & $\begin{array}{l}\text { Investigated glass ceiling in education } \\
\text { sector } 240 \text { faculty members from } 42 \\
\text { colleges as respondents found significant } \\
\text { differences on basis of gender }\end{array}$ \\
\hline 5 & $\begin{array}{l}\text { Bc Simona } \\
(2010)\end{array}$ & Glass ceiling in the corporate world & $\begin{array}{l}\text { Focused on various forms of gender } \\
\text { inequalities which creates barriers for } \\
\text { women advancement in career. }\end{array}$ \\
\hline 6 & $\begin{array}{l}\text { Dr. Kalpana Maheshwari } \\
\text { (2009) }\end{array}$ & $\begin{array}{l}\text { The glass ceiling impact on Indian } \\
\text { women } \\
\text { employees. }\end{array}$ & $\begin{array}{l}\text { Focused on cultural biases, } \\
\text { gender stereotypes and policies of } \\
\text { organizations in order to have a diverse } \\
\text { senior management. }\end{array}$ \\
\hline 7 & $\begin{array}{l}\text { Budhawar et al. } \\
\text { (2005) }\end{array}$ & $\begin{array}{l}\text { Women in Management in the New } \\
\text { economic Environment }\end{array}$ & $\begin{array}{l}\text { Found stereotyping as the main barrier } \\
\text { because of which women are offered less } \\
\text { challenging roles and are not involved in } \\
\text { important organizational issues }\end{array}$ \\
\hline 8 & $\begin{array}{lll}\begin{array}{l}\text { Sodeshini } \\
(2005)\end{array} & \text { Pillay } & \text { D }\end{array}$ & $\begin{array}{l}\text { A study of the barriers to career } \\
\text { progress of women in an } \\
\text { organization }\end{array}$ & $\begin{array}{l}\text { Presented the difficulties that women face } \\
\text { in order to progress not only in } \\
\text { management but also in other } \\
\text { occupations. Results have shown that } \\
\text { most females and male believe that the } \\
\text { glass ceiling is existing in the workplace. }\end{array}$ \\
\hline 9 & $\begin{array}{l}\text { Deepika Nath } \\
\quad(2000\end{array}$ & $\begin{array}{l}\text { Gently shattering the glass ceiling: } \\
\text { experiences of Indian women } \\
\text { managers }\end{array}$ & $\begin{array}{l}\text { Found that due to family and } \\
\text { organizational support Indian women } \\
\text { managers are reaching to highest levels of } \\
\text { executive suite }\end{array}$ \\
\hline 10 & Koshal \& Gupta (1998) & $\begin{array}{l}\text { women managers in India: } \\
\text { Challenges and opportunities. }\end{array}$ & $\begin{array}{l}\text { Found degree of existence of glass } \\
\text { ceiling in the largest democracy of the } \\
\text { world. It analyzed cultural barriers as the } \\
\text { most dominating barrier preventing } \\
\text { women from advancing to corporate } \\
\text { leadership. }\end{array}$ \\
\hline
\end{tabular}

Table 4:- Factors effecting glass ceiling

\begin{tabular}{|c|c|c|c|c|c|c|c|}
\hline $\begin{array}{l}\text { Sr. } \\
\text { No }\end{array}$ & $\begin{array}{l}\text { Factors } \\
\text { \& } \\
\text { Author name }\end{array}$ & F1 & F2 & F3 & F4 & F5 & F6 \\
\hline 1 & Sahana Sharma & $\checkmark$ & $\%$ & $\checkmark$ & & & \\
\hline 2 & $\begin{array}{l}\text { RobertoM. } \\
\text { Fermandez et.al }\end{array}$ & $\%$ & & & & & \\
\hline 3 & Len J.Trevino.et.al & $\%$ & $\checkmark$ & $\checkmark$ & & & \\
\hline 4 & $\begin{array}{l}\text { Jenny } \\
\text { M.Hobbleret.al }\end{array}$ & $\checkmark$ & 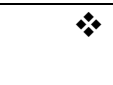 & $\checkmark$ & & & \\
\hline 5 & Garry N. Powell & $\checkmark$ & $\%$ & & & & \\
\hline 6 & Matt L. Huffman & $\checkmark$ & $\checkmark$ & $\checkmark$ & $\checkmark$ & & \\
\hline 7 & $\begin{array}{l}\text { Frank L Kwaku } \\
\text { Ohemeng et.al }\end{array}$ & $\checkmark$ & & & & $\%$ & \\
\hline 8 & $\begin{array}{ll}\text { Nicholas } & \text { A. } \\
\text { Palomeres } & \end{array}$ & $\checkmark$ & $\checkmark$ & & & & $*$ \\
\hline 9 & Janes R.Elliott & $\checkmark$ & & & & & $\%$ \\
\hline 10 & $\begin{array}{l}\text { Jerlando } \\
\text { F.L.Jackson et.al }\end{array}$ & $\checkmark$ & & & & & $*$ \\
\hline
\end{tabular}




\begin{tabular}{|c|c|c|c|c|c|c|c|}
\hline 11 & Linda K.Stroh & $*$ & $*$ & & & & $\checkmark$ \\
\hline 12 & $\begin{array}{l}\text { Annelies E.M Van } \\
\text { Vianen et.al }\end{array}$ & 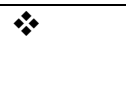 & $*$ & & & & 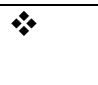 \\
\hline 13 & Marry C.Mattis & $\%$ & & & & & \\
\hline 14 & $\begin{array}{ll}\text { Patrice } & \text { M. } \\
\text { Buzzanell } & \end{array}$ & $\checkmark$ & $\checkmark$ & & & & $\checkmark$ \\
\hline 15 & Santa Clara & & & & & & $\%$ \\
\hline 16 & Andrew Reynolds & $\checkmark$ & & $\checkmark$ & & $\checkmark$ & \\
\hline 17 & Brenda J. Wrigley & $\checkmark$ & $\checkmark$ & $\checkmark$ & & $\checkmark$ & $\checkmark$ \\
\hline 18 & Schwartz & & & & & & $\%$ \\
\hline 19 & Cheryl Myers & $\%$ & & & & & \\
\hline 20 & Cody Bullock & & $\%$ & & & & \\
\hline 21 & Syeda Rownak & $\%$ & $\checkmark$ & $\checkmark$ & & & \\
\hline 22 & Bombuwela P.M & $\checkmark$ & $\%$ & $\checkmark$ & & & \\
\hline 23 & Amer Al Manasra & $\%$ & $\checkmark$ & $\checkmark$ & & & \\
\hline 24 & $\begin{array}{ll}\text { Oribanjo } & \text { Adewale } \\
\text { Omotayo } & \end{array}$ & & $\checkmark$ & $\%$ & & & \\
\hline 25 & Ann.M.Morrison & $\%$ & & & & & \\
\hline 26 & $\begin{array}{l}\text { Olukemi } \\
\text { I.Lawanson }\end{array}$ & $\checkmark$ & $\checkmark$ & $\checkmark$ & $*$ & $\checkmark$ & $\%$ \\
\hline 27 & Vlado Dimovski & $*$ & & & & & \\
\hline 28 & Thi Thu Thao Tran & $\checkmark$ & $\checkmark$ & & & & $\checkmark$ \\
\hline 29 & Sarmishta Nandy & $\checkmark$ & $\checkmark$ & $\checkmark$ & & & \\
\hline 30 & Deepak Nath & $\checkmark$ & $\checkmark$ & $\checkmark$ & & & \\
\hline & $\begin{array}{l}\text { Factors effecting } \\
\text { glass ceiling }\end{array}$ & $\begin{array}{ll}\checkmark & 16\end{array}$ & $\begin{array}{ll}\checkmark & 13\end{array}$ & $\begin{array}{ll}\checkmark & 12\end{array}$ & $\begin{array}{ll}\checkmark & 1\end{array}$ & $\checkmark \quad 3$ & $\checkmark \quad 4$ \\
\hline$*$ & $\begin{array}{l}\text { Most important } \\
\text { factor } \quad \text { effecting } \\
\text { glass ceiling }\end{array}$ & $* 10$ & $* 7$ & $* 1$ & $* 1$ & $* 1$ & $\$ 7$ \\
\hline
\end{tabular}

$\checkmark \quad$ = Factors effecting glass ceiling

* = Most important factor effecting glass ceiling

Table 5:- Evaluation of critical factors effecting glass ceiling.

\begin{tabular}{|c|c|c|c|}
\hline Code & Factor name & Factor effecting & Critical factor effecting \\
\hline F1 & Organizational factor & 16 & 10 \\
\hline F2 & Personal factor & 13 & 7 \\
\hline F3 & Socio-cultural factor & 12 & 1 \\
\hline F4 & Sexual harassment & 1 & 1 \\
\hline F6 & Political factor & 3 & 7 \\
\hline
\end{tabular}

\section{Findings:-}

1. Through Table 2 it was found that almost all studies show existence of glass ceiling in abroad, 2 studies showed that in today's time glass ceiling is shattering and only one study revealed non-existence of glass ceiling

2. Through Table 3 it was found that all studies show existence of glass ceiling in India except for one study of Deepika nath which revealed that glass ceiling is shattering in India

3. In Table 4 six factors promoting glass ceiling are identified on basis of reviews which includes organizational factors, personal factor, social-cultural factor, sexual harassment, political and stereotyping factor.

4. In Table 5 critical factors are evaluated and the sequence of factor effecting the most is
- Organizational factor
- Personal factor
$\circ$ Stereotyping factor 
- Socio - cultural factor

- Political factor

- Sexual harassment

\section{Conclusion:-}

To conclude through the findings glass ceiling is existing in India and abroad only weak evidence are found for its shattering. In today's technological period nations are on path of progress but progress of nations is also not supporting career advancement of women as studies reveal gender based glass ceiling is found across world, organizational factor is found to be the most critical factor which impedes career advancement of women in top positions.

\section{Recommendations:-}

1. Government should make strict rules and regulations to check glass ceiling, reports should be collected from organizations regarding promotions and its basis

2. Organizations should understand importance of women on top positions and fair practices should be followed in promotions

3. Awareness programmers regarding glass ceiling should be conducted for women

4. Women unions should be formed to raise voice against glass ceiling 